\title{
Bacteroides acidifaciens sp. nov., isolated from the caecum of mice
}

\author{
Yukiko Miyamoto and Kikuji Itoh
}

Department of Veterinary Public Health, Graduate School of Agriculture and Life Science, The University of Tokyo, Bunkyo-ku, Tokyo 113-8657, Japan
Author for correspondence: Kikuji Itoh. Tel: +8135841 5476. Fax: +81358418188. e-mail: akikuji@hongo.ecc.u-tokyo.ac.jp
Keywords: Bacteroides acidifaciens sp. nov., mouse intestine, 16S rRNA sequencing, acid production

\section{INTRODUCTION}

More than 50 bacteroides species are recognized in the Approved Lists of Bacterial Names (amended edition) (Skerman et al., 1989). These species exhibit a variety of cellular morphologies and are biochemically and physiologically extremely heterogeneous. Therefore, Shah \& Collins (1989) proposed on the basis of biochemical and chemical criteria that the genus Bacteroides should be restricted to Bacteroides fragilis and closely related organisms.

On the other hand, on the basis of the analysis of the 16S rRNA sequence, Bacteroides forms the CFB group with Cytophaga and Flavobacterium (Woese, 1987). The CFB group was divided into the cytophaga subgroup, flavobacterium subgroup, bacteroides subgroup, etc. The bacteroides subgroup was further divided into the Prevotella cluster, Porphyromonas cluster, Bacteroides cluster and two new clusters. The Bacteroides cluster was equivalent to the old 'Bacteroides fragilis group' except for Bacteroides distasonis and some other species (Paster et al., 1994).

Abbreviations: CFB, Cytophaga-Flavobacterium-Bacteroides; G6PDH, glucose-6-phosphate dehydrogenase; 6PGDH, 6-phosphogluconate dehydrogenase.

The DDBJ accession numbers for the 16S rRNA gene sequences of strains $A 1, A 8, A 24, A 29, A 31, A 32, A 37, A 40$ and $A 43$ are $A B 021158, A B 021157$, $A B 021159, A B 021160, A B 021161, A B 021162, A B 021163, A B 021164$ and $A B 021165$, respectively.
We isolated a number of characteristic anaerobic bacteria from the mouse caecum. The isolates lowered the $\mathrm{pH}$ of peptone-yeast broth with Fildes' digest (PYF) (Kaneuchi et al., 1979), acid fermentation by the isolates could not be evaluated. In this study, we attempted to clarify the genus and the species of these isolates. From the results of 16S rRNA gene sequence and DNA-DNA homology, we propose that these strains should be classified as a new species of the genus Bacteroides, Bacteroides acidifaciens.

\section{METHODS}

Bacterial strains and culture. Bacterial strains were isolated from the caecum of mice bred in our laboratory. Caecal contents were suspended and diluted with anaerobicbuffered (Mitsuoka et al., 1965). Then, each dilution was spread on Eggerth-Gangon (EG) agar (Eiken) and neomycin-brilliant green-taurocholate acid (NBGT) agar and incubated at $37^{\circ} \mathrm{C}$ in an anaerobic stainless steel jar filled with an atmosphere of $100 \% \mathrm{CO}_{2}$ by the steel-wool method (Parker, 1955). Strain A1, strain A24, and strains A29, 31, 32, 37, 40 and 43 were isolated from CF\#1, NC, and $\mathrm{BALB} / \mathrm{c}$, respectively. These isolates predominantly colonized in mouse intestines. All type strains used in this study were obtained from the Japan Collection of Microorganisms (JCM) and the German Collection of Microorganisms and Cell Cultures (DSMZ).

Biological and biochemical tests. Morphological and biochemical characteristics were determined by the methods described by Kaneuchi et al. (1976, 1979). For preparation 
Table 1. Characteristics that differentiate new isolates from phylogenetically closely related bacteroides species

JCM, Japan Collection of Microorganisms; DSM, German Collection of Microorganisms and Cell Cultures. Strains 1-6: 1, Bacteroides ovatus JCM 5824 ${ }^{\mathrm{T}}$ (= ATCC 8483 ${ }^{\mathrm{T}}$ ); 2, Bacteroides thetaiotaomicron JCM $5827^{\mathrm{T}}\left(=\right.$ ATCC $\left.29148^{\mathrm{T}}\right) ; 3$, Bacteroides uniformis JCM $5828^{\mathrm{T}}(=$ ATCC $\left.8492^{\mathrm{T}}\right) ; 4$, Bacteroides eggerthii DSM $20697^{\mathrm{T}}$ (= ATCC 27754 $)$; 5, Bacteroides vulgatus JCM

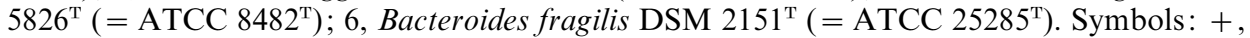
positive; ++ , strongly positive; - , negative. All strains were Gram-negative, and positive for aesculin hydrolysis and $\mathrm{NH}_{3}$ production; all strains showed excellent growth in $20 \%$ bile and had stimulated growth, i.e. more growth than in the PYG control tube.

\begin{tabular}{|c|c|c|c|c|c|c|c|c|c|c|c|c|c|c|}
\hline \multirow[t]{2}{*}{ Characteristic } & \multicolumn{14}{|c|}{ Strain/isolate: } \\
\hline & 1 & 2 & 3 & 4 & 5 & 6 & A24 & A31 & A43 & A32 & A1 & A37 & A29 & A40 \\
\hline Final $\mathrm{pH}$ & $5 \cdot 97$ & $5 \cdot 98$ & $6 \cdot 49$ & $6 \cdot 56$ & $6 \cdot 77$ & $6 \cdot 61$ & $5 \cdot 69$ & $5 \cdot 60$ & $5 \cdot 57$ & $5 \cdot 59$ & $5 \cdot 59$ & $5 \cdot 58$ & $5 \cdot 61$ & $5 \cdot 58$ \\
\hline End product* & SAp & SA & SAp & SAp & SAp & SAp & SA & SA & SA & SA & SA & SA & SA & SA \\
\hline Starch hydrolysis & + & + & + & + & - & + & - & - & - & + & + & + & + & + \\
\hline $\mathrm{H}_{2} \mathrm{~S}$ production & + & + & + & - & + & + & - & - & - & - & - & - & - & - \\
\hline Indole production & + & + & + & + & - & - & - & - & - & + & + & + & - & + \\
\hline Nitrate reduction & ++ & - & - & ++ & - & ++ & - & - & - & - & - & ++ & + & - \\
\hline Gelatin digestion & - & - & - & - & + & - & - & - & - & - & - & - & ++ & - \\
\hline G6PDH activity & ++ & + & + & + & + & ++ & ++ & ++ & ++ & ++ & ++ & ++ & ++ & ++ \\
\hline 6PGDH activity & + & + & + & ++ & + & + & ++ & + & + & + & ++ & ++ & ++ & + \\
\hline
\end{tabular}

* End products: S, Succinic acid; A, Acetic acid; P, Propionic acid; upper-case letters indicate 1 meq (or more) per $100 \mathrm{ml}$ culture; lower-case letters indicate less than $1 \mathrm{meq}$ per $100 \mathrm{ml}$ culture.

of inocula, peptone-yeast extract broth with $4 \%(\mathrm{v} / \mathrm{v})$ Fildes' digest [peptic digestive of horse blood (Fildes et al., 1936)] (PYF) was used.

End products. Strains were grown for $7 \mathrm{~d}$ in PYF with glucose. Fatty acids were analysed by GC according to the methods of Kaneuchi et al. (1976, 1979).

G6PDH and 6PGDH enzyme assay. Cells were suspended in $1 \mathrm{ml} \mathrm{Tris} / \mathrm{HCl}(\mathrm{pH} 7 \cdot 8)$, lysed by sonication at $4{ }^{\circ} \mathrm{C}$ and centrifuged at $17000 \mathrm{~g}, 20 \mathrm{~min}$ at $4{ }^{\circ} \mathrm{C}$ to remove cellular debris. The Bio-Rad protein assay was used to determine the protein concentration. The reaction mixture contained $160 \mu \mathrm{l}$ cell lysis supernatant, $20 \mu \mathrm{l}$ NADP $(5.4 \mathrm{mM}), 20 \mu \mathrm{l}$ NAD (5.4 mM), and $4 \mu 1$ glucose 6-phosphate as substrate. The G6PDH activity was measured at $340 \mathrm{~nm}$ after the incubation of the reaction mixture at $37^{\circ} \mathrm{C}$ for $10 \mathrm{~min}$. The substrate of the 6PGDH assay was changed to 6-phosphogluconic acid and the G6PDH assay was performed (Bailey \& Love, 1995).

16S rRNA gene sequencing and phylogenetic analysis. One bacterial colony was scraped from the agar plate and suspended in $50 \mu \mathrm{l} \mathrm{TE}$ buffer, then frozen at $-20^{\circ} \mathrm{C}$ and heated three times at $100{ }^{\circ} \mathrm{C}$ for $5 \mathrm{~min}$ each. This raw extracted DNA was used as template DNA for PCR. PCR amplification was performed with a DNA thermal cycler (Takara). PCR mixture contained $10 \times \mathrm{EX}$ Taq buffer $(10 \mu \mathrm{l})$, a mixture of dNTPs $(2 \cdot 5 \mathrm{mM})(8 \mu \mathrm{l}), 4 \mu \mathrm{l}$ of each of the primers $(20 \mathrm{pM})\left(8 \mathrm{~F}, 5^{\prime}\right.$-AGA GTT TGA TCM TGG CTC AG; 15R, 5'-AAG GAG GTG ATC CAR CCG CA), $1 \mu \mathrm{l}$ raw template DNA and 3 U EX Taq (Takara). Distilled water was added to make $100 \mu \mathrm{l}$, and $50 \mu \mathrm{l}$ mineral oil was then added. Initially, these mixtures were preheated for 3 min at $72{ }^{\circ} \mathrm{C}, 35$ cycles of amplification in total were performed with template DNA denaturation at $94{ }^{\circ} \mathrm{C}$ for $30 \mathrm{~s}$, followed by annealing of primers at $55^{\circ} \mathrm{C}$ for $30 \mathrm{~s}$, and extension of primers at $72^{\circ} \mathrm{C}$ for $2 \mathrm{~min}$, and finally postheating for $2 \mathrm{~min}$ at $94^{\circ} \mathrm{C}$. The PCR products were separated by electrophoresis in agarose gels and stained with ethidium bromide $\left(1 \mu \mathrm{g} \mathrm{ml}^{-1}\right)$. PCR products were purified by MicroSpin S-400 HR columns (Pharmacia) according to the manufacturer's instructions. The $16 \mathrm{~S}$ rRNA gene sequence was determined by direct PCR sequencing using the method of Anzai et al. (1997). The 16S rRNA gene sequences of other Gram-negative bacteria were available in GenBank, EMBL and DDBJ. Levels of sequence similarity were calculated and used to produce an unrooted phylogenetic tree by the neighbour-joining method (Saitou \& Nei, 1987). The alignment and the stability of relationships were assessed by bootstrapping using CLUSTAL W (Thompson et al., 1994).

Determination of $\mathbf{G}+\mathbf{C}$ content. High-molecular-mass DNA of bacterial strains was prepared by the procedures of Marmur (1961) with minor modifications. Determination of DNA base composition by reversed-phase HPLC was performed as described by Tamaoka \& Komagata (1984).

DNA-DNA hybridization. DNA of bacterial strains was prepared by the procedures of Marmur (1961) with minor modifications. DNA-DNA hybridization was performed as described by Ezaki et al. (1989).

\section{RESULTS}

\section{Biochemical and biological characterization}

All of the strains in this study showed similar colony and cell forms. They were obligately anaerobic Gramnegative rods. The most remarkable characterization of these strains was that the final $\mathrm{pH}$ which was less than 5.7 in PYF broth after $7 \mathrm{~d}$ incubation. A 


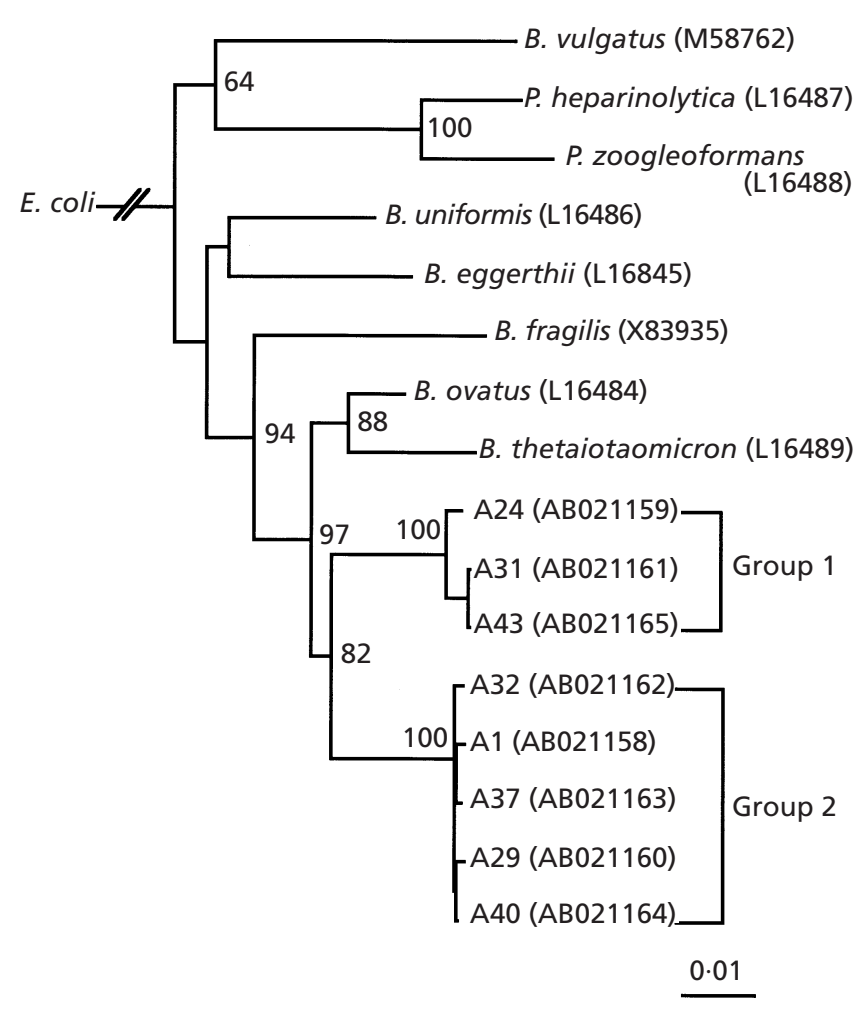

Fig. 1. Dendrogram of the eight isolates and their reference strains in the Bacteroides cluster and $E$. coli analysed using CLUSTAL W (Thompson et al., 1994). Prevotella heparinolytica and Prevotella zoogleoformans were previously classified in the genus Bacteroides. GenBank accession numbers are given in parentheses. Bar indicates a genetic distance of 0.01.

comparison of these isolates and type strains for biological characterization are shown in Table 1. G6PDH and 6PGDH activity, end production of succinic and acetic acids, growth stimulation in $20 \%$ bile acid, aesculin hydrolysis, no production of $\mathrm{H}_{2} \mathrm{~S}$ and production of $\mathrm{NH}_{3}$ were common features of all strains. Starch hydrolysis, indole production and nitrate reduction were different among the strains. Only strain A29 digested gelatin.

\section{Analysis of $16 \mathrm{~S}$ rRNA sequence}

Approximately $1500 \mathrm{bp}$ regions of the 16S rRNA gene for these isolates were sequenced. These sequences suggested strong similarity for the species in the Bacteroides cluster. A phylogenetic tree of the relationship between the type strains in the Bacteroides cluster and the isolates is shown in Fig. 1. The range of $16 \mathrm{~S}$ rRNA sequence homology between the isolates and type strains in the Bacteroides cluster was 91.5$95 \cdot 3 \%$.

This tree suggested that the isolates can be divided in two groups, with strains A1, A29, A32, A37 and A40 belonging to group 2 of Fig. 1 and A24, A31 and A43 belonging to group 1 of Fig. 1. 16S rRNA sequence homology between groups 1 and 2 was $98 \cdot 2 \%$.

\section{DNA-DNA hybridization}

To confirm whether these strains are new species, DNA-DNA hybridization was performed. All isolates showed a low level of homology against the type strains (Table 2). Homology between the isolates was over $80 \%$ (Table 2 ).

\section{DISCUSSION}

In this report, we describe the isolates of a novel Bacteroides species predominantly colonized in the mouse caeca. Their characteristics, i.e. obligately anaerobic, Gram-negative, good growth in bile acid, and aesculin hydrolysis, and G6PDH and 6PGDH

Table 2. Percentage DNA-DNA hybridization of the new isolates with biotin-labelled DNA from type strains of some species of the genus Bacteroides

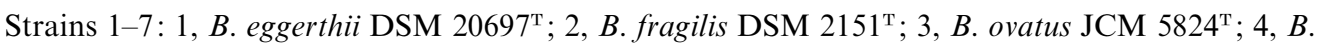

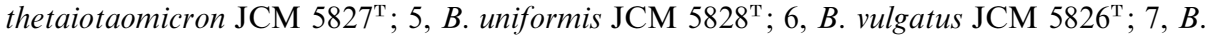
distasonis JCM $5825^{\mathrm{T}}$. Data are percentage homology to reference DNA.

\begin{tabular}{|c|c|c|c|c|c|c|c|c|c|c|c|}
\hline \multicolumn{2}{|c|}{ Labelled DNA from: } & \multicolumn{10}{|c|}{ Unlabelled DNA from strain/isolate: } \\
\hline Isolate & $\begin{array}{l}\mathrm{G}+\mathrm{C} \\
\mathrm{mol} \%\end{array}$ & 1 & 2 & 3 & 4 & 5 & 6 & 7 & A31 & A40 & A37 \\
\hline A24 & $41 \cdot 5$ & 8.6 & $2 \cdot 0$ & $12 \cdot 6$ & $6 \cdot 1$ & 5.9 & $3 \cdot 0$ & 3.0 & $84 \cdot 7$ & $85 \cdot 0$ & $83 \cdot 6$ \\
\hline A31 & $40 \cdot 8$ & $12 \cdot 3$ & $8 \cdot 7$ & $14 \cdot 7$ & $12 \cdot 9$ & $7 \cdot 1$ & $7 \cdot 8$ & $2 \cdot 0$ & $100 \cdot 0$ & 87.7 & 84.9 \\
\hline A43 & $39 \cdot 8$ & $16 \cdot 6$ & $5 \cdot 4$ & $7 \cdot 1$ & $9 \cdot 4$ & $7 \cdot 5$ & 11.8 & $4 \cdot 1$ & $100 \cdot 0$ & $102 \cdot 3$ & $91 \cdot 4$ \\
\hline A32 & 41.9 & $9 \cdot 5$ & $3 \cdot 1$ & $9 \cdot 1$ & $7 \cdot 1$ & $5 \cdot 8$ & $2 \cdot 4$ & $4 \cdot 5$ & $91 \cdot 2$ & 97.8 & $95 \cdot 0$ \\
\hline A1 & $42 \cdot 2$ & $0 \cdot 0$ & $0 \cdot 0$ & 0.0 & $18 \cdot 8$ & $0 \cdot 0$ & $8 \cdot 0$ & $8 \cdot 6$ & $84 \cdot 7$ & $89 \cdot 2$ & $93 \cdot 3$ \\
\hline A37 & $39 \cdot 4$ & $9 \cdot 0$ & $2 \cdot 4$ & $7 \cdot 9$ & $7 \cdot 8$ & $2 \cdot 8$ & $1 \cdot 8$ & $0 \cdot 0$ & $94 \cdot 8$ & 92.6 & $100 \cdot 0$ \\
\hline A29 & $41 \cdot 8$ & $8 \cdot 6$ & 1.9 & $11 \cdot 3$ & $5 \cdot 5$ & $4 \cdot 6$ & $1 \cdot 3$ & $1 \cdot 2$ & $81 \cdot 6$ & $88 \cdot 1$ & $82 \cdot 6$ \\
\hline A 40 & $41 \cdot 4$ & $16 \cdot 5$ & $0 \cdot 4$ & $14 \cdot 6$ & $9 \cdot 6$ & $11 \cdot 8$ & $3 \cdot 7$ & $7 \cdot 4$ & $104 \cdot 3$ & $100 \cdot 0$ & $96 \cdot 5$ \\
\hline
\end{tabular}


activity suggested that these isolates were contained in the 'Bacteroides fragilis group'. The specific character of these strains was reduction of the $\mathrm{pH}$ of PYF broth without carbohydrate.

16S rRNA gene sequence analysis suggested that these isolates belong to a new species in the Bacteroides cluster in the bacteroides subgroup. The low level of DNA-DNA hybridization with the type strains of other species in the Bacteroides cluster confirmed the novel species status of these isolates.

Inter-individual genetic heterogeneity of these isolates was suggested from 16S rRNA analysis. Starch hydrolysis suggested their heterogeneity. All biological and biochemical characters of strains in group 1 were the same. Strain A29 was slightly different from the other four strains in group 2 in indole production and gelatin digestion. However, homology of the $16 \mathrm{~S}$ rRNA sequence between group 1 and group 2 was about $98 \cdot 2 \%$ and DNA-DNA homology between the isolates of group 1 and group 2 was over $80 \%$. Therefore, these two groups appeared to be one species (Stackebrandt \& Goebel, 1994).

\section{Description of Bacteroides acidifaciens sp. nov.}

Bacteroides acidifaciens (a.ci.di'fa'ci.ens. M.L. n. acidum acid; L. v. facio produce; M.L. part. adj. acidifaciens acid-producing).

Cells are obligately anaerobic, non-sporeforming, nonmotile, Gram-negative rods. Cells grown on EG agar plates are $0.8-1.3 \times 1.6-8.0 \mu \mathrm{m}$. Colonies on EG agar plates after two days incubation are $1-3 \mathrm{~mm}$ in diameter, circular, entire, raised convex, smooth and greyish-coloured. Acid is produced from prereduced anaerobically sterilized peptone-yeast extract broth with Fildes' digest (PYF) without any carbohydrate. Aesculin hydrolysis, $\mathrm{NH}_{3}$ production and G6PDH and 6PGDH enzyme activities are positive, and $\mathrm{H}_{2} \mathrm{~S}$ production is negative. The major end products of glucose fermentation are acetic and succinic acids. The $\mathrm{G}+\mathrm{C}$ content of DNA is $39 \cdot 4-42 \cdot 2 \mathrm{~mol} \%$. At the molecular level, this species can be distinguished from other Bacteroides species by the sequence of the $16 \mathrm{~S}$ rRNA gene. Strain $\mathrm{A} 40^{\mathrm{T}}$ is the type strain and has been deposited in the Japan Collection of Microorganisms as JCM $10556^{\mathrm{T}}$.

\section{ACKNOWLEDGEMENTS}

The authors wish to thank Dr T. Mitsuoka for his helpful advice in naming Bacteroides acidifaciens.

\section{REFERENCES}

Anzai, Y., Kudo, Y. \& Oyaizu, H. (1997). The phylogeny of the genera Chryseomonas, Flavimonas, and Pseudomonas supports synonymy of these three genera. Int J Syst Bacteriol 47, 249-251.
Bailey, G. D. \& Love, D. N. (1995). Glucose 6-phosphate dehydrogenase and 6-phosphogluconate dehydrogenase activities and glucose utilization by species within the genera Bacteroides, Prevotella and Porphyromonas. Int J Syst Bacteriol 45, 246-249.

Ezaki, T., Hashimoto, Y. \& Yabuuchi, E. (1989). Fluorometric deoxyribonucleic acid-deoxyribonucleic acid hybridization in microdilution wells as an alternative to membrane filter hybridization in which radioisotopes are used to determine genetic relatedness among bacterial strains. Int J Syst Bacteriol 39, 224-229.

Fildes, P., Richardson, G. M., Knight, B. C. G. E. \& Gladstone, G. P. (1936). A nutrient mixture suitable for growth of Staphylococcus aureus. Br J Exp Pathol 17, 481-484.

Kaneuchi, C., Watanabe, K., Terada, A., Benno, Y. \& Mitsuoka, T. (1976). Taxonomic study of Bacteroides clostridiiformis subsp. clostridiiformis (Burri and Ankersmit) Holdeman and Moore and of related organisms: proposal of Clostridium clostridiiformis (Burri and Ankersmit) comb. nov. and Clostridium symbiosum (Stevens) comb. nov. Int J Syst Bacteriol 26, 195-204.

Kaneuchi, C., Miyazato, T., Shinjo, T. \& Mitsuoka, T. (1979). Taxonomic study of helically coiled, sporeforming anaerobes isolated from the intestines of humans and others animals: Clostridium cocleatum sp. nov. and Clostridium spiroforme sp. nov. Int J Syst Bacteriol 29, 1-12.

Marmur, J. (1961). A procedure for the isolation of deoxyribonucleic acid from micro-organism. J Mol Biol 3, 208-218.

Mitsuoka, T., Sega, T. \& Yamamoto, S. (1965). Eine vervesserte methodik der qualitativen und quantitativen analyse der darmflora von menschen und tieren. Zentbl Bakteriol Parasitenkd Infektkrankh Hyg Abt I Orig 27, 961-979.

Parker, C. A. (1955). Anaerobiosis with iron wool. Aust J Exp Biol Med Sci 33, 33-38.

Paster, B. J., Dewhirst, F. E., Olsen, I. \& Fraser, G. J. (1994). Phylogeny of Bacteroides, Prevotella, and Porphyromonas spp. and related bacteria. J Bacteriol 176, 725-732.

Saitou, N. \& Nei, M. (1987). The neighbor-joining method: a new method for reconstructing phylogenetic trees. Mol Biol Evol 4, 406-425.

Shah, H. N. \& Collins, M. D. (1989). Proposal to restrict the genus Bacteroides (Castellani and Chalmers) to Bacteroides fragilis and closely related species. Int J Syst Bacteriol 39, 85-87.

Skerman, V. B. D., McGowan, V. \& Sneath, P. H. A. (editors) (1989). Approved Lists of Bacterial Names (amended edition). Washington, DC: American Society for Microbiology.

Stackebrandt, E. \& Goebel, B. M. (1994). Taxonomic note: a place for DNA-DNA reassociation and 16S rRNA sequence analysis in the present species definition in bacteriology. Int $J$ Syst Bacteriol 44, 846-849.

Tamaoka, J. \& Komagata, K. (1984). Determination of DNA base composition by reverse-phase high-performance liquid chromatography. FEMS Microbiol Lett 25, 125-128.

Thompson, J. D., Higgins, D. G. \& Gibson, T. J. (1994). CLUSTAL $\mathrm{W}$ : improving the sensitivity of progressive multiple sequence alignment through sequence weighting, position-specific gap penalties and weight matrix choice. Nucleic Acids Res 22, 4673-4680.

Woese, C. R. (1987). Bacterial evolution. Microbiol Rev 51, 221-271. 